\title{
Release of hydrogen peroxide by phagocytes from bovine colostrum in the peripartum period
}

\author{
Viviani Gomes, Karina Medici Madureira, Sergio Soriano, Gerlândia Neres Pontes, \\ Bruno Toledo Silva, Alice Melville Paiva Della Libera, Fernando José Benesi \\ University of São Paulo, College of Veterinary Medicine and Animal Science, \\ São Paulo, Brazil \\ Received November 6, 2013 \\ Accepted April 24, 2014
}

\begin{abstract}
Changes in the composition of colostrum in the peripartum period focused on the neonate's immunity can minimize the response of the mammary gland before natural exposure to mastitis pathogens. This research evaluated the oxidative activity of mononuclear and polymorphonuclear phagocytes of bovine colostrum. Bacteriologically negative $(n=171)$ bovine colostrum samples of first and second milking postpartum were evaluated. The oxidative activity was assessed by the production of hydrogen peroxide $\left(\mathrm{H}_{2} \mathrm{O}_{2}\right)$ released either spontaneously or upon stimulation by enterotoxigenic Escherichia coli (ETEC). For this, three treatments were used: control (C) - only cells; non-opsonized (NO) - cells and ETEC non-opsonized; and opsonized (O) - cells and ETEC opsonized. Median values of concentrations $\left(\mathrm{nmol} / 10^{6}\right)$ of $\mathrm{H}_{2} \mathrm{O}_{2}$ produced by cells obtained from the first and second milking treatments $\mathrm{C}$, NO and O were 149.1 and $39.9(P=0.0007) ; 125.5$ and $49.1(P=0.0007) ; 102.4$ and $54.4(P=0.008)$, respectively. No differences were observed between the treatments at each milking. The amount of $\mathrm{H}_{2} \mathrm{O}_{2}$ produced at first milking exceeded the values found thereafter. Furthermore, the presence of bacteria did not determine the increased amount of $\mathrm{H}_{2} \mathrm{O}_{2}$ released by phagocytes. Thus, we concluded that the mammary gland's events during the peripartum period have an effect on the proportion and activity of phagocytes, which can cause injuries to the breast parenchyma by the large amount of free radicals produced. The high frequency of bovine mastitis during this period indicates the need for studies of the immunity of the mammary gland and research of susceptibility factors for bacterial infections.
\end{abstract}

Bovine colostrum, cell, bactericidal activity, cow, mammary secretion

Changes in the composition of colostrum in the peripartum period focused on the neonate's immunity can minimize the response of the mammary gland before its natural exposure to mastitis pathogens. The immune components of colostrum include viable cells, enzymes, immunoglobulins, and cytokines (Tóthová et al. 2007; Stelwagen et al. 2009).

The proportion of colostrum cell components varies with the stage of lactation. It is noteworthy that colostrum in the immediate postpartum period shows a large percentage of phagocytes, especially macrophages and epithelial cells $(69.5 \pm 17.4 \%)$, on the other hand, neutrophil population is very small (13.3 $\pm 19.4 \%$ ) (Gomes et al. 2011a). These cells are involved in the non-specific immunity of the mammary gland, and release chemotactic factors and pro-inflammatory cytokines which are responsible for the recruitment of polymorphonuclear leukocytes (PMN) from the blood stream to the udder. Recognition and phagocytosis of the bacteria by PMN cells are made easier by the opsonization of the microorganism with immunoglobulins (IgG2 and $\mathrm{IgM}$ ), and factors of the complement system (C3b). After phagocytosis, bacteria are destroyed by dependent and independent oxygen mechanisms (Paape et al. 2002, 2003).

Study of the peculiarities of the innate immune response in the immediate postpartum period is limited by the difficulty of isolating colostrum mononuclear leukocytes (Meganck et al. 2014). Thus, the knowledge available comes from studies that were carried out with

Address for correspondence:

Viviani Gomes

University of São Paulo, College of Veterinary Medicine and Zootechnics

Avenida Prof. Dr. Orlando Marques de Paiva, 87

Cidade Universitária, Butantã, São Paulo, 05508-270, Brazil

Phone: +55 1130911331

Fax: +55 1130911283

E-mail: viviani.gomes@usp.br

http://actavet.vfu.cz/ 
phagocytes obtained from blood or milk. The high frequency of bovine mastitis during the colostrogenesis and immediate postpartum period (Hogan and Smith 2012) indicates the need for studies of the immunity of the mammary gland and research of susceptibility factors for bacterial infections. The main pathogens isolated from colostrum are coagulasenegative Staphylococcus and Streptococcus agalactiae. However, higher incidence of clinical mastitis in the postpartum period has been associated with infections caused by Escherichia coli (Dingwell et al. 2002; Rajala-Schultz et al. 2005; Molina et al. 2013).

The hypothesis of this research is that the disharmony between the proportions and cell types of the mammary gland during the peripartum compromise the innate defense mechanisms of tissue, such as phagocytosis, generation of free radicals, and bactericidal activity of phagocytes. Thus, the objective of this study was to evaluate the indirect bactericide activity of the mononuclear $(\mathrm{MN})$ and PMN cells from bovine colostrum by spontaneous release of $\mathrm{H}_{2} \mathrm{O}_{2}$ or after stimulation with Escherichia coli.

\section{Materials and Methods}

Animals and samples

Unpaired bacteriologically negative samples of colostrum $(n=171$ to each treatment) were obtained from udder quarters of cows and heifers that were separated from their calves immediately after parturition. These samples were collected in the beginning of the first and second milking, at most $12 \mathrm{~h}$ after delivery, with milking breaks at most $8 \mathrm{~h}$. Prior to collection of the samples, the cows were examined according to the criteria established by Dirksen et al. (1993), obtaining the samples of colostrum only from mammary quarters free of clinical and subclinical mastitis. The udders were cleaned with a $2 \%$ water and hypochlorite solution; then they were dried, and teat orifices were disinfected with $70 \%$ ethanol.

We harvested three aliquots of each sample of whole colostrum, as follows: (1) the first aliquot (80 ml) was added in sterile plastic bottles containing $80 \mathrm{ml}$ of phosphate buffered saline (PBS), (2) the second aliquot consisted of $20 \mathrm{ml}$ of pure colostrum, and (3) the third aliquot $(3 \mathrm{ml})$ was stored in sterile glass vials.

\section{Obtaining of colostrum cells}

To obtain and separate cells, the first aliquot was centrifuged at $600 \times g$ for $15 \mathrm{~min}$ at $4{ }^{\circ} \mathrm{C}$. The centrifugation step enabled the separation of colostrum into three distinct phases: cell pellet, an intermediate fluid portion, and a fat layer. The upper portion, composed of fat and fluid, was discarded. The cell pellet was resuspended in $10 \mathrm{ml}$ of cell culture medium (RPMI 1640 medium, Sigma ${ }^{\mathrm{TM}}$ ) and centrifuged at $600 \times \mathrm{g}$ for $15 \mathrm{~min}$ at $4{ }^{\circ} \mathrm{C}$. This procedure was repeated $\times 3$ to wash the cells. Cell viability in the pooled suspension was assessed by Trypan blue exclusion test, and cells were diluted to $2 \times 10^{6}$ cells $/ \mathrm{ml}$.

\section{Escherichia coli opsonization}

The second aliquot of colostrum was used to obtain colostral serum, which was used for the opsonization of ETEC in indirect bactericide activity trials of phagocytes. Enterotoxigenic E. coli (F5) was cultured in Tryptic Soy Broth (TSB, Difco ${ }^{\mathrm{TM}}$, Detroit, USA) for $18 \mathrm{~h}$ at $37^{\circ} \mathrm{C}$, washed twice in PBS, and cell concentration was adjusted to approximately $2 \times 10^{8}$ cells $/ \mathrm{ml}$, as measured by turbidimetry at $540 \mathrm{~nm}$ on a Coleman spectrophotometer (Celm, Brazil). This bacterial concentration was previously determined by colony counts on Tryptic Soy Agar (TSA, Difco ${ }^{\mathrm{TM}}$, Detroit).

To obtain opsonins, the second colostrum aliquot of $10 \mathrm{ml}$ was centrifuged at $2000 \times g$ for $1 \mathrm{~h}$. After centrifugation, whey was separated and aliquots were placed in $3 \mathrm{ml}$ microtubes to assess bacterial opsonization and to evaluate bactericide activity of the cells in each sample, according to the method previously described by Bellinati-Pires et al. (1989).

For the opsonization of $E$. coli, colostrum aliquots were thawed immediately before use and mixed with appropriate volumes of bacterial suspension to a final concentration of $2 \times 10^{7}$ bacteria/ml (Meynell and Meynell 1965), in a 10\% opsonin source. As an untreated bacterial control, another bacterial suspension was prepared at the same concentration in cell culture medium without opsonins. Both bacterial suspensions were incubated for $30 \mathrm{~min}$ at $37^{\circ} \mathrm{C}$ and used in the bactericide treatments.

\section{Evaluation of oxidative activity}

Three treatments were performed to evaluate the oxidative activity of the cells in bovine colostrum, as follows: Treatment 1 measured spontaneous $\mathrm{H}_{2} \mathrm{O}_{2}$ release by the cells (Control); Treatment 2 measured $\mathrm{H}_{2} \mathrm{O}_{2}$ release following the stimulation of the cells with non-opsonized E. coli (non-opsonized - NO); and Treatment 3 measured $\mathrm{H}_{2} \mathrm{O}_{2}$ release following the stimulation with $E$. coli that was opsonized with $10 \%$ delipidated colostrum supernatant (opsonized - O). 
Horseradish peroxidase-dependent oxidation of phenol red, which is assessed by its increased absorbance at $600 \mathrm{~nm}$ (Pick and Mizel 1981; Russo et al. 1989), is a sensitive method to measure $\mathrm{H}_{2} \mathrm{O}_{2}$ release from phagocytic cells. Briefly, suspensions of cells $\left(2 \times 10^{6}\right.$ cells $\left./ \mathrm{ml}\right)$ were mixed with overnight $E$. coli cultures $\left(2 \times 10^{7}\right.$ bacteria $\left./ \mathrm{ml}\right)$ that were inactivated for $1 \mathrm{~h}$ at $60^{\circ} \mathrm{C}$; the procedure was performed in duplicate, and the co-cultures were stirred at $37^{\circ} \mathrm{C}$ for $30 \mathrm{~min}$. Phagocytosis was halted by incubating co-cultures in an ice bath. To eliminate any extracellular bacteria, suspensions were centrifuged twice $(600 \times g$ for $10 \mathrm{~min}$ at $\left.4^{\circ} \mathrm{C}\right)$.

Cells were resuspended in a phenol red solution consisting of $140 \mathrm{mM} \mathrm{NaCl}, 10 \mathrm{mM}$ potassium phosphate, $\mathrm{pH} 7.0,5.5 \mathrm{mM}$ dextrose, $0.56 \mathrm{mM}$ phenol red and $0.01 \mathrm{mg} / \mathrm{ml}$ type II horseradish peroxidase (Sigma $\left.{ }^{\mathrm{TM}}\right)$. Then, $0.1 \mathrm{ml}$ of each sample was transferred to a flat-bottomed, 96-well culture plate (Corning ${ }^{\mathrm{TM}}$ ). Spontaneous $\mathrm{H}_{2} \mathrm{O}_{2}$ release by the cells was measured in the samples that contained cells alone. The samples were incubated for $1 \mathrm{~h}$ at $37^{\circ} \mathrm{C}$ in humidified atmosphere, and the reaction was terminated by adding $10 \mathrm{~mL}$ of $1 \mathrm{~N} \mathrm{NaOH}$.

Absorbance was measured by enzyme-linked immunosorbent assay in an automatic photometer that was equipped with a 630-nm filter. Results were expressed as $\mathrm{nM} \mathrm{H}_{2} \mathrm{O}_{2}$ per $2 \times 10^{6}$ cells, calculated based on a standard curve that consisted of known molar $\mathrm{H}_{2} \mathrm{O}_{2}$ concentrations in buffered phenol red.

\section{Bacteriological examination}

The third aliquot was aseptically obtained for bacteriological examination and cultured on Petri dishes with 5\% sheep blood agar and Sabouraud agar. The cultures were kept at $37^{\circ} \mathrm{C}$ for 24 to $48 \mathrm{~h}$. Bacterial microorganisms were characterized according to morphological, staining and biochemical cultivation. Samples that were positive for any microorganism in the bacteriological analysis were excluded from the study (Lennette 1985).

\section{Statistical analysis}

Due to the difference in physico-chemical properties of the milk secretion obtained before the first and second milking postpartum, it was decided to distribute them into groups and analyze them separately. The quantity of $\mathrm{H}_{2} \mathrm{O}_{2}$ showed a nonparametric distribution by the Kolmogorov-Smirnov test. The median of the quantity of $\mathrm{H}_{2} \mathrm{O}_{2}$ produced was calculated and differences among the $\mathrm{C}, \mathrm{NO}$ and $\mathrm{O}$ treatments were analyzed by Mann-Whitney test.

\section{Results}

Median values of hydrogen peroxide released by phagocytes from colostrum, stimulated or non-stimulated by Escherichia coli bacteria, are shown in Table 1.

Table 1. Oxidative activity $\left(\mathrm{nmol} / 10^{6}\right)$ of cells found in bovine colostrum, according to the different treatments, in samples collected before the first and second milking.

\begin{tabular}{|c|c|c|c|c|c|c|}
\hline \multirow{2}{*}{$\begin{array}{l}\text { Treatments } \\
\text { Milking order }\end{array}$} & \multicolumn{2}{|c|}{$\mathrm{C}$} & \multicolumn{2}{|c|}{$\mathrm{NO}$} & \multicolumn{2}{|c|}{$\mathrm{O}$} \\
\hline & $1^{\text {st }}$ & $2^{\text {nd }}$ & $1^{\text {st }}$ & $2^{\text {nd }}$ & $1^{\text {st }}$ & $2^{\text {nd }}$ \\
\hline Mean & 134.5 & 71.4 & 127.0 & 68.8 & 131.0 & 75.5 \\
\hline Standard deviation & 87.9 & 65.1 & 80.8 & 58.6 & 94.6 & 64.8 \\
\hline Median & $149.1^{\mathrm{a}}$ & $39.9^{b}$ & $125.5^{\mathrm{a}}$ & $49.1^{\mathrm{b}}$ & $102.4^{\mathrm{a}}$ & $54.4^{b}$ \\
\hline Minimum & 8.1 & 3.1 & 13.2 & 4.5 & 17.8 & 4.5 \\
\hline Maximum & 273.2 & 264.4 & 297.3 & 325.7 & 296.0 & 273.6 \\
\hline$P$ value & \multicolumn{2}{|c|}{0.0007} & \multicolumn{2}{|c|}{0.0007} & \multicolumn{2}{|c|}{0.008} \\
\hline
\end{tabular}

$\mathrm{C}$ - Control; NO - Non-opsonized; O - Opsonized

a,b - Values with different lower case letters in the same row indicate statistical differences between them $(P<0.05)$

The median values of $\mathrm{H}_{2} \mathrm{O}_{2}\left(\mathrm{nmol} / 10^{6}\right)$ produced were higher in the first milking independent of the assay performed. Values of 149.1 and $39.9(P=0.0007), 125.5$ and 49.1 $(P=0.0007)$, and 102.4 and $54.4(P=0.008)$, were obtained in the first and second milking postpartum, respectively, in $\mathrm{C}, \mathrm{NO}$ and $\mathrm{O}$ treatments.

The median value of hydrogen peroxide produced between $\mathrm{C}, \mathrm{NO}$ and $\mathrm{O}$ assays was similar $(P>0.05)$, independent of the number of milking postpartum. However, increasing values of $\mathrm{H}_{2} \mathrm{O}_{2}\left(\mathrm{nmol} / 10^{6}\right)$ were observed in $\mathrm{C}$, $\mathrm{NO}$ and $\mathrm{O}$ assays only in the second milking postpartum. 


\section{Discussion}

Phagocytosis, oxidative burst, and bacterial death are among the innate defense mechanisms that are employed by phagocytic cells in the host's defense stimulated by microorganisms (Paape et al. 2003). This study evaluated the oxidative activity of phagocytes in bovine colostrum by measuring $\mathrm{H}_{2} \mathrm{O}_{2}$ released either spontaneously or after stimulation with $E$. coli, which is an important agent of bovine mastitis.

Spontaneous release of $\mathrm{H}_{2} \mathrm{O}_{2}$, which demonstrates the activation status of cells, was observed in bovine colostrum cells. Median $\mathrm{H}_{2} \mathrm{O}_{2}$ concentrations in this study were greater than those found by Pontes (1999) in human colostrum using the same colorimetric technique for the measurement of $\mathrm{H}_{2} \mathrm{O}$, by colostrum phagocytes. It should be noted that human colostrum is significantly different than bovine colostrum. Human colostrum has a lower somatic cell count (SCC), predominance of IgA, and greater proportion of neutrophils $(60 \%)$, whereas bovine colostrum has higher cell concentration, about $1 \times 10^{6}$ cells/ml of colostrum, with the predominance of macrophages.

The amount of $\mathrm{H}_{2} \mathrm{O}_{2}$ produced at first milking exceeded the values found thereafter. $\mathrm{H}_{2} \mathrm{O}_{2}$ is released by macrophages and PMNs after phagocytosis. Macrophages are the predominant cells in bovine colostrum (Gomes et al. 2011a); they may locate both opsonized and nonopsonized particles and phagocyte and destroy them intracellularly (Pick and Mizel 1981). Unspecific phagocytosis by bovine colostrum macrophages may have contributed to the lack of significant differences between the treatments in this study, because colostrum contains a high concentration of fat globules and other substances, which may have been engulfed and could, thus, stimulate the release of $\mathrm{H}_{2} \mathrm{O}_{2}$ in the absence of $E$. coli.

The presence of bacteria did not determine the increased amount of $\mathrm{H}_{2} \mathrm{O}_{2}$ released by phagocytes. However, a trend was observed in the amplification of the colostrum phagocytes response obtained in the $2^{\text {nd }}$ milking postpartum, in the presence of Escherichia coli compared to bacterial assays without stimulation. We believe that the macrophages that are present in bovine colostrum $(69.5 \pm 17.4 \%)$ before the first milking (Gomes et al. 2011a) have a lower microbicidal activity toward bacteria compared to neutrophils. Therefore, the latter cells depend on the opsonization of bacteria with $\operatorname{IgG}_{2}$ and $\mathrm{IgM}$ for optimum phagocytosis, but the major immunoglobulin of bovine colostrum is the $\mathrm{IgG}_{1}$ (Gomes et al. 2011b).

Smaller proportion of PMN in the first milking postpartum is due to a decreased expression of the L-selectin molecule, responsible for the migration of PMN from blood to udder tissue (Paape et al. 2002, 2003), which could justify the higher proportion of neutrophils in the second milking colostrum reported in a previous research by our team (Gomes et al. 2011a). This is an important factor that may be related to the greater prevalence of bovine mastitis in the peripartum period (Burvenich et al. 1994).

We conclude that the low activity of phagocytes for E.coli might represent a susceptibility factor for the mammary gland to bacterial infections in the immediate postpartum period. Furthermore, the large amount of free radicals produced can cause injuries to the udder parenchyma.

\section{References}

Bellinati-Pires R, Melke SE, Colleto GMDD, Carneiro-Sampaio MMS 1989: Evaluation of a fluorochrome treatment for assessing the bactericidal activity of neutrophils in human phagocyte dysfunctions. J Immunol Methods 119: 189-196

Burvenich C, Paape MJ, Hill AW, Guidry AJ, Miller RH, Heyneman R, Kremer WDJ, Brand A 1994: Role of the neutrophil leukocyte in the local and systemic reactions during experimentally induced colimastitis in cows immediately after calving. Vet Q 16: $45-50$

Dingwell RT, Duffield TF, Leslie KE, Keefe GP, Descoteaux L, Kelton F, Lissemore KD, Schukken YH, Dick P, Bagg R 2002: The efficacy of intramammary tilmicosin at drying-off, and other risk factors for the prevention of new intramammary infections during the dry period. J Dairy Sci 85: 3250-3259 
Dirksen G, Gründer HD, Stöber M 1993: Clinical examination of cattle. Guanabara Koogan, Rio de Janeiro, Brazil, 419 p.

Gomes V, Madureira KM, Della Libera AMMP, Blagitz MG, Alves M, Baptistela F, Benesi FJ 2011a: Dynamics of colostrum cellularity of Holstein cows in the immediate postpartum period (in Portuguese). Arq Bras Med Vet Zootec 63: 1047-1053

Gomes V, Madureira KM, Soriano S, Della Libera AMMP, Blagitz MG, Benesi FJ 2011b: Factors affecting immunoglobulin concentration in colostrum of healthy Holstein cows immediately after delivery (in Portuguese). Pesq Vet Bras 31: 53-56

Hogan J, Smith KL 2012: Managing environmental mastitis. Vet Clin Food Animal 28: 217-224

Lennette EH 1985: Manual of Clinical Microbiology. American Society of Microbiology, Washington, 1149 p.

Meganck V, Goddeeris BM, Stuyven E, Piepers S, Cox E, Opsomer G 2014. Development of a method for isolating bovine colostrum mononuclear leukocytes for phenotyping and functional studies. Vet J 200: 294-298

Meynell GG, Meynell E 1965: Theory and practice in experimental bacteriology. Cambridge University Press, $346 \mathrm{p}$.

Molina LR, Gentilini MB, Carvalho, AU, Facury Filho EJ, Moreira GHFA, Moreira LPV, Gonçalves RL 2013: Use of an Escherichia coli J5 vaccine on immunization of dairy cows against mastitis caused by E. coli (In Portuguese). Pesq Vet Bras 33: 291-298

Paape MJ, Bannerman DD, Zhao X, Lee JW 2003: The bovine neutrophil: structure and function in blood and milk. Vet Res 34: 597-627

Paape MJ, Mehrzad J, Zhao X, Detilleux J, Burvenich C 2002: Defense of the bovine mammary gland by polymorphonuclear neutrophil leukocytes. J Mammary Gland Biol 7: 109-121

Pick E, Mizel D 1981: Rapid microassays for the measurement of superoxide and hydrogen peroxide production by macrophages in culture using an automatic enzyme immunoassay reader. J Immunol Methods 46: 211-226

Pontes GN 1999: Assessment of phagocytic and microbicidal activity of cells of human colostrum for Salmonella typhimurium (In Portuguese). MS Thesis. Instituto de Ciências Biomédicas, Universidade de São Paulo, São Paulo, $114 \mathrm{p}$.

Rajala-Schultz PJ, Hogan JS, Smith KL 2005: Association between milk yield at dry-off and probability of intramammary infections at calving. J Dairy Sci 88: 577-579

Russo M, Teixeira HC, Marcondes MC, Barbuto JA 1989: Superoxide-independent hydrogen peroxide release by activated macrophages. Braz J Med Biol Res 22: 1271-1273

Stelwagen K, Carpenter E, Haigh B, Hodgkinson A, Wheeler TT 2009: Immune components of bovine colostrums and milk. J Anim Sci 87: 3-9

Tóthová CS, Nagy O, Seidel H, Konvičná J, Farkašová Z, Kováč G 2007: Acute phase proteins and variables of protein metabolism in dairy cows during the pre- and postpartal period. Acta Vet Brno 77: 51-57 